\title{
ВПЛИВ ЕКЗО- ТА ЕНДОГЕННИХ ЧИННИКІВ НА МОРФОЛОГІЮ ПІДШЛУНКОВОЇ ЗАЛОЗИ (ОГЛЯД ЛІТЕРАТУРИ)
}

Вплив екзо- та ендогенних чинників на морфологію підшлункової залози (огляд літератури)

Н. П. Зикова, 3. М. Небесна, С. Б. Крамар, С. О. Литвинюк

Тернопільський національний медичний університет імені І. Я. Горбачевського МОЗ України

Резюме. Cтаття присвячена вивченню та детальному аналізу статей та наукової літератури щодо морфоофункціональних особливостей ремоделювання підшлункової залози при різноманітних впливах на організм. Підшлункова залоза разом з іншими залозами беруть участь у регуляції фрункцій організму, тому порушення їі діяльності під впливом різноманітних чинників є актуальною темою.

Мета дослідження - вивчити і проаналізувати сучасні дані науковців щодо впливу різноманітних чинників на реорганізацію підшлункової залози та виокремити нові перспективні морфологічні погляди на дослідження органа.

Матеріали і методи. Матеріалом для статmі були наукові публікації за останні роки, що стосувалися впливу різноманітних чинників на морфологічні особливості підшлункової залози.

Результати. У дослідженні розглянуто літературні дані впливу на підшлункову залозу солей важких металів, наркотичних і токсичних речовин, алкоголю, тютюнокуріння, голодування, ожиріння, гравітаційних навантажень, кисневого голодування, гіпероксигенації, гіпотермії, дегідратації, недостатньої кількості йоду, лікарських препаратів, вірусних інфеекцій, а також при дії електричного струму. Проте невелика кількість наукових джерел присвячена впливу термічного фрактора на стан підшлункової залози.

Висновки. Зәідно з аналізом літературних джерел, вивчено вплив значної кількості зовнішніх та внутрішніх чинників на підшлункову залозу. Проте вплив термічних опіків шкіри на морфрофункціональний стан залози у сучасних наукових статтях практично не зустрічається, тому дана проблема потребує подальших досліджень.

Ключові слова: підшлункова залоза; морфофункціональні зміни; екзогенний та ендогенний чинники.
Influence of exo- and endogenous factors on pancreas morphology (literature review)

N. P. Zykova, Z. M. Nebesna, S. B. Kramar, S. O. Lytvynyuk

I. Horbachevsky Ternopil National Medical University

e-mail: nebesna_zm@tdmu.edu.ua

Summary. The article is devoted to the study and detailed analysis of articles and scientific literature on the morphofunctional features of pancreatic remodeling with various effects on the body. The pancreas, along with other glands involved in the regulation of body functions, so the violation of its activities under the influence of various factors is a topical issue.

The aim of the study - to learn and analyze the current data of scientists on the influence of various factors on the reorganization of the pancreas and to identify new promising morphological views on the study of the organ.

Materials and Methods. The material for the article was scientific publications in recent years on the influence of various factors on the morphological features of the pancreas.

Results. The article considers the literature on the effects on the pancreas of salts of heavy metals, drugs and toxic substances, alcohol, smoking, starvation, obesity, gravity, oxygen starvation, hyperoxygenation, hypothermia, dehydration, iodine deficiency, drugs, and viral infections. under the action of electric current. However, a small number of scientific sources are devoted to the influence of thermal factors on the condition of the pancreas.

Conclusions. According to the analysis of literature sources to date, the influence of a significant number of external and internal factors on the pancreas has been studied. However, the effect of thermal skin burns on the morphofunctional state of the gland in modern scientific articles is almost non-existent, so this problem requires further research.

Key words: pancreas; morphofunctional changes; exogenous and endogenous factors. 


\section{ВСТУП}

Підшлункова залоза є важливим органом, який виконує ряд фрункцій в організмі. Орган регулюється нейрогуморальними механізмами і бере участь у регуляції білково-вуглеводно-жирового обмінів, порушення яких призводить до тяжких наслідків у тканинах і органах організму [1]. Результати дор сліджень у численних літературних джерелах, що стосуються впливу негативних чинників на підшлункову залозу, є суперечливими. Тому їх дев тальний аналіз допоможе встановити найбільш часті зміни органа при впливі різноманітних екстремальних чинників.

Метою дослідження було вивчити і проаналізувати сучасні дані науковців щодо впливу різноманітних чинників на реорганізацію підшлункової залози та виокремити нові перспективні морфологічні погляди на дослідження органа.

\section{МАТЕРІАЛИ I МЕТОДИ}

Матеріалом для статті були наукові публікації за останні роки, що стосувалися впливу різноманітних чинників на морфологічні особливості підшлункової залози.

\section{РЕЗУЛЬТАТИ Й ОБГОВОРЕННЯ}

Серед великої кількості наукових даних найбільше уваги присвячено змінам підшлункової залози, які викликані найбільш розповсюдженими чинниками.

Серед важких металів, що мають суттєвий токсичний вплив на функцію підшлункової залози, виділяють мідь, марганець, цинк, свинець, хром. Це призводить до стуктурної перебудови тканини підшлункової залози у вигляді порушеннь мікроциркуляції, атрофрії екзо- та ендокринних клітин, розростаннням сполучної тканини та накопичення солей металів у тканинах органа. Досліджено, що ступінь і вираження змін залежать від комбінації солей та терміну їх споживання. Найбільш виражені зміни викликає комбінація солей свинець-хром-цинк, найменші - цинк-мідь-залізо. Після припинення впливу даних металів на організм, будова органа повністю не відновлювалась [2]. Інші автори ввав жають, що вплив хрому (у вигляді харчових добавок) на організм неоднозначний, у малих дозах впливає на нормалізацію вуглеводного, білкового, а також жирового обмінів, а у великих дозах - знижувалась активність панкреатичних фрерментів (амілаза і ліпаза) в плазмі крові [3]. Вплив водного розчину урану на залозу знижує ії синтетичну активність та розвивається екзокринна недостатність [4]

Проведені дослідження з перитонеальним введенням L-аргініну і таурохолату натрію у різних доі зах, показало розвиток гострого панкреатиту в щу- рів. Проте якщо припинити вплив даних речовин, то швидше відновлення залози відбувається після застосування таурохолату натрію $[5,6]$.

Досліджено, що надходження нітратів в організм впливає на підвищення вмісту продуктів ліпідного обміну в підшлунковій залозі, що свідчить про низьку активність ферментативної ланки [7].

Автори довели, що усі опіоїдні речовини (на відміну від ендорфінів, які діють вибірково на певні рецептори організму) впливають на всі рецептори одночасно. Вплив налбуфіну, як різновиду опіоїдних речовин, на підшлункову залозу визначалося деструктивними змінами гемо- та лімфоциркуляторного русла, системи вивідних проток, морфофрункціональними змінами екзо- та ендокриноцитів, стромального компонента залози [8, 9]. Водночас, автори вказують, що морфологічні зміни підшлункової залози залежать від терміну вживання, виду наркотичної речовини та їх комбінації [10].

Негативний вплив алкоголю на організм, а зокрема підшлункову залозу, вивчили багато науковців. Порушення фрункціонального стану органа відбувається навіть при одноразовому прийомі алкоголю. А при систематичному вживанні, його токсичний вплив проявляється у порушенні гемомікроциркуляторного русла, що впливає на порушення трофріки залози, і як наслідок, розвиток незворотних дегенеративних процесів: заміщення паренхіми органа сполучнотканинною стромою, що порушує його фрункцію з подальшим розвитком цукрового діабету $[11,12]$.

Останні дані наукових досліджень абсолютно довели, що тютюнокуріння сприяє прогресуванню панкреатиту і появі раку залози. У даний процес залучений гіпоталамус, у якому знаходяться два центри, що відповідають за відчуття голоду і сид тості. При вживанні нікотину активується центр ситості й пригнічується центр голоду. Відбувається спазм кровоносних судин та системи вивідних проток, що викликає запальні реакції в органі [13].

I. В. Лещенко вивчав тривалий вплив глутамату натрію на підшлункову залозу. Автор встановив, що щоденне введення глутамату натрію щурам в дозі 15 мг/кг і 30 мг/кг (відповідно 1 і 2 г на середньостатистичну людину) впродовж 30-ти днів викликало збільшення маси тіла майже в два рази, і як наслідок - ожиріння та розвиток гострого панкреатиту. Даний препарат посилює засвоєння їжі та зменшення енергетичних витрат. На гістологічному рівні, зі збільшенням терміну досліду наростали дистрофрічні та некротичні зміни екзо- й ендокриноцитів. Площа ядер збільшувалась, а площа клітин зменшувалась, збільшувалось ядерно-цитоплазматичне співвідношення. Спостерігався периваскулярний та інтерстиційний набряк сполучної тканини з ознаками фріброзу. Виявлялась лейкоцитарна інфрільтрація та стази в просвітах судин [14]. 
На відміну від ожиріння, ряд авторів дослідив вплив голодування на підшлункову залозу. Дослідження показали взаємозв'язок між голодуванням та зменшенням рівня цукру в крові [15].

За результатами дослідження, введення гормонального препарату - мелатоніну мишам у різний час доби та пори року показав, що у весняний період мелатонін підвищував ознаки синтетичної активності екзо- та ендокринної частин, а в осінній період - спостерігалось зниження екзокринної та підвищення ендокринної активності $[16,17]$.

І. В. Захарова вивчала вплив гравітаційних навантажень на організм щурів. Даний чинник викликає в підшлунковій залозі зміни, які мають виражену залежність від тривалості впливу даного фоктора. Короткотривала дія гравітаційних перевантажень призводить до гіпертрофрічних змін 3 боку нервової системи та білоксинтезуючого апарату ендокриноцитів острівців Лангерганса, проте не порушує секреторний процес в екзокринній частині залози. Довготривалий і повторювальний вплив гравітаційних перевантажень викликає компенсаторно-пристосувальні й деструктивні зміни. В ациноцитах гальмується виділення гранул зимогену, різке кровонаповнення залози, а також деструктивні зміни в ендотеліоцитах, порушення секреторного процесу в панкреатичних острівцях, особливо у В-клітинах [18].

Також було досліджено вплив на підшлункову залозу довготривалого перебування щурів в екстремальних умовах високогір'я. Доведено, що чим більший час перебування у горах, тим більш виражені структурні зміни підшлункової залози - набряк і розростання строми та атрофрія екзокринної паренхіми [19].

У роботах вчених-морфологів знайдено дані про вплив кисневого голодування та надмірного вмісту кисню в крові на стан підшлункової залози. В умовах гіпоксії (до 5 год) спостерігаються дистрофрічні зміни, що призводять до гіпофункції залози і порушення білкового обміну. Починаючи з 5 год після впливу, в ациноцитах крім репаративних процесів, спостерігався початок компенсаторної гіперфуннції залози. Про гіпоксію підшлункової залози свідчили такі особливості ультраструктури, як: набряк ендотеліоцитів гемокапілярів, розширення міжклітинних прошарків, зміни органел клітин (редукція гранулярної ендоплазматичної сітки та елементів комплексу Гольджі, набряк мітохондрій).

При гіпероксигенації в ранні терміни експерименту спостерігалась активація екзокриноцитів (наявність великої кількості розширених цистерн гранулярної ендоплазматичної сітки, велика кількість рибосом, гіпертрофія і гіперплазія комплексу Гольджі). Це свідчило про підвищений синтез білків, що, ймовірно, є компенсаторною реакцією екзокринної клітини на дію токсичних доз кисню.
У пізні терміни гіпероксигенації відзначалася нормалізація ультраструктури підшлункової залози $[20,21]$.

У науковій літературі відзначається, що гіпотермія (переохолодження організму) чинить негативний ефрект на структурну організацію підшлункової залози - поява набряку строми, порушення гемомікроциркуляції та секреторного циклу екзокриноцитами. 3 активацією холодових рецепторів спостерігався викид біологічно активних речовин, які фоормували еферентну відповідь у нервовій, травній та серцево-судинній системах, щоб відновити вихідний температурний стан тіла [22, 23]. Інші автори вважають, що найбільш вираженою ознакою гіпотермії це обезводнення клітин, яке проявляється у втраті 80 \% води та призводить до порушення комплексу макромолекул, зокрема денатурації білків [24].

А. В. Савищев (2010) та інші автори вказують, що при короткотривалій гіпотермії спостерігаються не суттєві зміни в підшлунковій залозі. В екзокринній частині виявляли зміни ультраструктури ациноцитів: розширення цистерн гранулярної ендоплазматичної сітки, з її частковою дегрануляцією, часткова редукція комплексу Гольджі, набряк ядер ендотеліоцитів гемокапілярів, зниження метаболічних процесів. Проте при гіпертермії виникали більш серйозні зміни екзокринної та ендокринної частин, що супроводжувалось порушенням секреторного циклу [25].

Доведений той фракт, що дегідратація організму має безпосередній зв'язок зі станом підшлункової залози. Деструктивні зміни строми, паренхіми та гемомікроциркуляторного русла наростали прямо пропорційно ступеню дегідратації [26].

Підшлункова залоза надто чутлива до ряду лікарських препаратів («Парацетамол», «Німесулід», «Морфін», «Ізоніазид» та ін.), які при тривалому вживанні або при великих дозах чинять негативний вплив на її фрункцію, що проявлялось морфофонкціональними змінами, характерними для панкреатиту (вакуольна дистрофрія, некрози, порушення структури ацинусів) $[27,28]$.

О. В. Остапенко та В. І. Утєхин досліджували вплив гіпотиреозу на підшлункову залозу. Даним дослідженням автори показали, що тиреоїдні гормони мають безпосередній вплив на залозу. Недостатність гормонів щитоподібної залози впливають на структурні зміни строми і паренхіми органа, що проявлялось у зниженні синтетичної фрункції залози. Міжчасточкова сполучна тканина виглядала набряклою та щільною, більшість ацинусів складалась із 3-4 одноядерних екзокриноцитів. Також відсутність гормонів щитоподібної залози негативно впливає на рівень синтезу ДНК, цитоплазматичної РНК, обміну білків у підшлунковій залозі [29, 30].
Вісник медичних і біологічних досліджень Bulletin of Medical and Biological Research
$4(6), 2020$ 
Деякі автори виявили закономірність між появою гострого панкреатиту з ураженням тканин головного мозку (у вигляді множинних абсцесів) [31]. Також у ділянці гіпоталамуса, гіпокампа, мозочка та кори головного мозку знайшли рецептори, які чутливі до інсуліну і тому при ушкодженні даних ділянок відбувається порушення секреції гормонів ендокриноцитами підшлункової залози [32].

Автори показали, що при короткотривалій дії електричного струму в підшлунковій залозі розвивались морфоорункціональні зміни, які проявлялись набряком строми та паренхіми, порушенням кровопостачання і вогнищевим запаленням, проте дані зміни в процесі експерименту мали зворотний характер [33].

Більшість авторів вивчала вплив вірусних інфекцій на залозу вірусів гепатиту - HBV, HCV, цитомегаловірусу, простого герпесу. Особливе значення має розвиток панкреатиту на фоні вірусних гепатитів В і С, вірусу СНІДу, проте через латентний перебіг останнього лікарі не звертають увагу на стан підшлункової залози [34, 35].

\section{СПИСОК ЛІТЕРАТУРИ}

1. Сравнительная морфология поджелудочной железы экспериментальных животных и человека / Я. И. Гущин, В. В. Шедько, А. А. Мужикян [и др.] // Лабораторные животные для научных исследований. 2018. - № 3. - С. 33-48.

2. Кравець О. В. Морфологічні та реадаптаційні зміни в підшлунковій залозі під впливом солей важких металів (анатомо-експериментальне дослідження) : автореф. дис. на здобуття наук. ступеня канд. мед. наук : 14.03.01 / О. В. Кравець ; Харк. нац. мед. ун-т. - Х., 2009. $-22 \mathrm{c}$.

3. Лебедев С. В. Морфобиохимические показатели и активность пищеварительных фрерментов у крыс линии wistar под влиянием различных источников хрома / С. В. Лебедев, И. А. Гавриш, И. З. Губайдуллина // Сельскохозяйственная биология. - 2019. - Т. 54, № 2. C. 304-315. doi: 10.15389/agrobiology.2019.2.304rus

4. Воронцова 3. А. Биоэфрфекты экзокринной и эндокринной паренхимы органов на обедненный / 3. А. Воронцова, А.С. Гуреев // The journal of scientific articles «Health \& education millennium». - 2013. - Vol. 15, № 1-4. - P. 250-252.

5. Зіненко Д. Ю. Ультраструктурна характеристика гемомікроциркуляторного русла та паренхіматозностромальних елементів підшлункової залози та печінки в моделі гострого панкреатиту з використанням різних доз таурохолату натрію / Д. Ю. Зіненко, І.В.Твердохліб // Морфологія. - 2020. - Т. 14, № 1. - С. 23-34. doi: https:// doi.org/10.26641/1997-9665.2020.1.23-34.

6. Береговенко І. М. Мікроциркуляторні й патоморфрологічні зміни підшлункової залози у розвитку експериментального гострого панкреатиту у щурів / I. М. Береговенко, Д. Ю. Зіненко, І. В. Твердохліб // Вісник проблем біології і медицини. - 2016. - № 1(2). - С. 331-334.
Також із сучасних досліджень було встановлено, що вірус COVID-19 негативно впливає на метан болізм глюкози, що сприяє розвитку цукрового діабету. Підвищений рівень цукру в крові забезпечує реплікацію вірусної інфрекції, що сприяє поширенню SARS-CoV-2 вірусу в організмі [36, 37].

Серед сучасних джерел надзвичайно мало даних, які б висвітлювали інфрормацію про морфоофункціональні зміни підшлункової залози при термічних опіках шкіри, тому даний напрямок досліджень $є$ актуальним і перспективним [38, 39].

\section{ВИСновки}

Підсумовуючи вищезазначене, можна стверджувати, що підшлункова залоза зазнає значних структурних змін при впливі різноманітних чинників. Характер та глибина цих змін часто залежать від тривалості дії негативних фракторів, концентрації речовин та їх природи. Серед проаналізованих джерел є лише незначна кількість робіт, що присвячена впливу термічних опіків на морфрофункціональний стан підшлункової залози, тому дана проблема потребує подальших досліджень.

7. Пономаренко Н. В. Вплив насіння амаранту на склад та пероксидне окислення ліпідів у підшлунковій залозі перепелів за дії нітратів : автореф. дис. на здобуття наукю ступеня канд. с.-г. наук : 03.00.04 / Н. В. Пономаренко ; Нац. аграр. ун-т. - К., 2007. - 21 с.

8. Михалевич М. М. Морфологічні зміни органів за впливу опіоїдів / М. М. Михалевич // Клінічна анатомія та оперативна хірургія. - 2019. - Т. 18, № 4. - С. 133-145. DOI: 10.24061/1727-0847.18.4.2019.21

9. Попик П. М. Особливості мікроструктури підшлункової залози білого щура за умов впливу опіоїду / П. М. Попик // Вісник проблем біології і медицини. - 2014. - T. 2, № 3. - С. 310-313.

10. Иммуноморфологическая характеристика поджелудочной железы при действии на организм наркотических веществ / Д. М. Шабдарбаева, Н. Б. Саякенов, Б. Р. Алимбекова, М.Н.Лепесбаев // Современная медицина: актуальные вопросы. - 2015. - № 2(38). C. $90-102$.

11. Ошмянская Н. Ю. Особенности гибели и регенерации клеток поджелудочной железы на ранних этапах развития алкогольного хронического панкреатита / Н. Ю. Ошмянская, А.А. Галинский, Ю. А. Гайдар // Вісник Дніпропетровського університету. Біологія, медицина. 2014. - № 5(2). - С. 138-142. doi:10.15421/021426.

12. Кліщ І. М. Вплив хронічної етанолової інтоксикації на репродуктивну систему / І. М. Кліщ, С. О. Нестерук // Вісник медичних і біологічних досліджень. - 2020. - № 3(5). - C. 161-166. doi: 10.11603/bmbr.2706-6290.2020.3.11527.

13. Куріння при панкреатиті - вплив тютюну на підшлункову залозу. Медичний онлайн довідник. [Електронний ресурс]. Режим доступу: https://virgo.org.ua/index. php/gastroenterologiya/10352-kurinnja-pri-pankreatiti-vplivtjutjunu. 
14. Лещенко І. В. Структурно-фрункціональний стан підшлункової залози за умов розвитку ожиріння : автореср. дис. на здобуття наук. ступеня канд. біол. наук : 03.00.13 / І. В. Лещенко ; Київський національний університет імені Тараса Шевченка МОН України. - К., 2020. - 21 с.

15. Григорова Н. В. Стан панкреатичних клітин $\beta$ дорослих і старих мишей після впливу гострого голодування та введення атропіну / Н. В. Григорова, А. П. Хмелевська // Актуальні питання біології, екології та хімії. - 2016. - Т. 12, № 2. - С. 33-40.

16. Давидова Н. В. Особливості впливу мелатоніну на окремі біохімічні показники плазми крові щурів за умов алоксанового діабету / Н. В. Давидова // Актуальні проблеми сучасної медицини. - 2016. - Т. 16, вип. 4(1). - C. 242-244.

17. Янко Р. В. Морфологічні зміни підшлункової залози після введення мелатоніну у різні сезони року / Р. В. Янко // Фізіол. журн. - 2016. - Т. 62, № 6. - С. 88-94.

18. Захарова И. В. Строение поджелудочной железы после воздействия на организм гравитационных перегрузок теория / И. В. Захарова // Морфология. - 2006. - T. 129, № 1. - C. 60-65.

19. Слынько Т. Н. Структурные изменения в поджелудочной железе в процессе деадаптации к высокогорью / Т. Н. Слынько, М. Я. Великородова, Н.Н.Заречнова // Бюллетень сибирской медицины. - 2009. - № 1(2). C. $69-72$.

20. Бархина Т. Г. Ультраструктура поджелудочной железы в условиях изменения газовой среды / Т. Г. Бархина, М. В. Донской, А. В. Савищев // Сб. науч. трудов Всероссийской юбилейной конференции паталогоанатомов, посвященной 100-летию профр. П. Г. Подзолкова. - Красноярск. - 2008. - С. 94-95.

21. Савищев А. В. Морфогенез поджелудочной железы на этапах онтогенеза при экспериментальном моделировании под воздействием стрессогенных факторов / А. В. Савищев, А. А. Молдавская. - Астрахань ; Москва. - 2011. - 164 с.

22. Степанян Ю. С. Морфофрункциональные эквиваленты реакции поджелудочной железы на гипотермию / Ю. С. Степанян // Проблемы экспертизи в медицине. - 2008. - № 2. - С. 22-24.

23. Дорошкевич С. В. Опыт криомоделирования патологии поджелудочной железы / С. В. Дорошкевич, П. Г. Пивченко, Е. Ю. Дорошкевич // Экспериментальная и клиническая гастроэнтнрология. - 2010. - № 8. C. $52-55$.

24. Патофизиологические аспекты экспериментального криомоделирования патологических состояний поджелудочной железы / А. Н. Курзанов, Н. В. Заболотских, В. В. Мясникова, А. В. Шестопалов // Кубанский научный медицинский весник. - 2016. № 6(116). - С. 97-100.

25. Савищев А. В. Электронно-микроскопическая характеристика поджелудочной железы при изменении температурного режима / А. В. Савищев // Известия высших учебных заведений. Поволжский регион. Медицинские науки. - 2010. - № 4(16). - С. 11-17.

26. Гістоморфометрична оцінка змін підшлункової залози за умов гіперосмолярної дегідратації / В. Ю. Ковчун, В. 3. Сікора, М. С. Линдін, В. В. Сікора // Буковинський медичний вісник. - 2020. - Т. 24, № 2. - С. 52-56.
27. Патоморфологические изменения ткани поджелудочной железы крыс при длительном приеме нимесулида / Л. В. Лазаренко, П. В. Косарева, Е. И. Самоделкин, В. П. Хоринко // Пермский медицинский журнал. - 2016. - T. XXXIII, № 4. - С. 78-81.

28. Вікторов О. П. Побічні реакції при медичному застосуванні ліків і підшлункова залоза / О. П. Вікторов // Здоров'я України. - 2009. - Тематичний номер. - С. 56-57.

29. Остапенко О. В. Ультраструктурные изменения ациноцитов поджелудочной железы крыс в динамике развития врожденного гипотиреоза / О. В. Остапенко, Ю. Б. Чайковский // Биомедицина. - 2014. - № 1. C. $38-44$.

30. Утехин В. И. Панкреатический эпителий в условиях гипотироза / В. И. Утехин // Вестник СанктПетербургского университета. - 2015. - № 2. - С. 89-111.

31. Абрамович А. А. Клинический случай в хирургической практике: острый идиопатический панкреатит, осложненный множественными абсцессами полушарий головного мозга / А. А. Абрамович, С. Н. Стяжкина, A. X. Шарипова // Научно-образовательный журнал для студентов и преподавателей «StudNet». - 2021. Вип. 1. - С. 125-130.

32. Аметов А. С. Гомеостаз глюкозы и метаболическая гибкость у здоровых людей / А. С. Аметов, Я. В. Пуговкина // Эндокринология: новости, мнения, обучение. - 2020. - Т. 9, № 4. - С. 12-22. doi: https://doi. org/10.33029/2304-9529-2020-9-4-12-22.

33. Морфологические изменения во внутренних органах у лабораторных животных в эксперименте при электротравме / В. У. Убайдуллаева, А. Ж. Фаязов, Д. Б. Туляганов [и др.] // Вестник экстренной медицины. - 2019. - Т. 12, № 1. - С. 54-61.

34. Зубрицкий М. Г. Морфологические изменения в поджелудочной железе при остром герпетическом менингоэнцесралите / М. Г. Зубрицкий // Журнал ГрГМУ. - 2006. - № 1. - C. 53-56.

35. Бабінець Л. С. Інфекційні чинники у формуванні патології підшлункової залози / Л. С. Бабінець, О. Р. Шайген // Медична газета «Здоров'я України 21 сторіччя». [Електронний ресурс]. 2017 [цитовано 2021 Лют 11]. 1(398). Режим доступу: http://health-ua.com/article/25968nfektcjn-chinniki-uformuvann-patolog-pdshlunkovo-zalozi.

36. Бабенко А. Ю. Сахарный диабет и COVID 19. Как они связаны? Современные стратегии борьбы / А. Ю. Бабенко, М. Ю. Лаевская // Артериальная гипертензия. - 2020. - Т. 26, № 3. - С. 304-311. doi:10.18705/1607419X-2020-26-3-304-311.

37. Новая коронавирусная инорекция (covid-19) и сахарный диабет: взгляд стоматолога / А. И. Сабирова, А. Б. Мамытова, И. А. Акрамов, И. С. Сабиров // The scientific heritage. - 2021. - № 58. - P. 44-51.

38. Elbassuoni E. A. Impact of chronic exercise on counteracting chronic stress-induced functional and morphological pancreatic changes in male albino rats / E. A. Elbassuoni, S. M. Abdel Hafez // Cell Stress Chaperones. - 2019. - No. 24(3). - P. 567-580. DOI: $10.1007 / \mathrm{s} 12192-019-00988$.

39. Mouse models in burns research: Characterisation of the hypermetabolic response to burn injury / J. Hew, R. Parungao, H. Shi [et al.] // Burns. - 2020. - No. 46 (3). P.663-674.DOI:https://doi.org/10.1016/j.burns.2019.09.014.
ISSN 2706-6282(print)

ISSN 2706-6290(online) 


\section{REFERENCES}

1. Gushchin Ya, Shedko V, Muzhikyan A, Makarova M, Makarov V. [Comparative morphology of the pancreas of experimental animals and humans]. Lab zhyvot dlya nauch iss. 2018;(3): 33-48. Russian.

2. Kravets OV. [Morphological and readaptational changes in the pancreas under the influence of heavy metal salts [abstract]. Kharkiv "Kharkiv National Med. University"; 2011. 25 p. Ukrainian.

3. Lebedev SV, Gavrish IA, Gubaydullina IZ. [Different chrome sources influence on morphobiochemical indicators and activity of digestive enzymes in wistar rats]. Selsk biol. 2019; 54(2):304-315. DOI: 10.15389/ agrobiology.2019.2.304rus. Russian.

4. Vorontsova ZA, Gureev AS. [Biotffects exocrine and endocrine parenchyma organs on depleted uranium]. The journal of scientific articles "Health \& education millennium". 2013; 15(1-4): 250-252. Russian.

5. Zinenko DYu, Tverdokhlib IV. [Ultrastructural characteristics of the hemomicrocirculatory bed and parenchymatous-stromal elements of the pancreas and liver in a model of acute pancreatitis using different doses of sodium taurocholate]. Morphologiya. 2020;14(1): 23-34. DOI: $\quad$ https://doi.org/10.26641/1997-9665.2020.1.23-34. Ukrainian.

6. Beregovenko IM, Zinenko DYu, Tverdokhlib IV. [Microcirculation and pathomorphological changes of pancreas in development of an experimental acute pancreatitis in rats]. Visn probl boil i med. 2016;1(2): 331-4. Ukrainian.

7. Ponomarenko NV. [Influence of amaranth seeds on the composition and peroxidation of lipids in the pancreas of quails under the action of nitrates [abstract]. Bila Tserkva State Agrarian University of the Ministry of Agrarian Policy of Ukraine; 2007. 23p. Ukrainian.

8. Mykhalevych MM. [Morphological changes of organs under the influence of opioid]. Klin anat $\mathrm{i}$ oper khirur. 2019;18(4): 133-45. DOI: 10.24061/17270847.18.4.2019.21. Ukrainian

9. Popyk PM. [Microstructure characteristics of pancreas white rat under influence opioid]. Visn probl boil i med. 2014.2(3): 310-3. Ukrainian

10. Shabdarbaeva DM, Sayakenov NB, Alimbekova BR, Lepesbaev MN. [Immunomorphological characteristics of the pancreas when exposed to drugs]. Sovrem med: actual vopr. 2015;2(38): 90-102. Russian.

11. Oshmyanska NY, Galinsky AA, Gaidar YA. [Peculiarities of death and regeneration of pancreas cells at early stages of alcoholic chronic pancreatitis]. Visnyk Dnipropet univer biol med. 2014;(5(2)): 138-42. DOI:10.15421/021426. Russian.

12. Klishch. IM, Nesteruk SO. [The effect of chronic ethanol intoxication on the reproductive system]. Visn med i boil dosl. 2020;3(5): 161-6. DOI: 10.11603/bmbr.27066290.2020.3.11527. Ukrainian.

13. [Medical online directory. Smoking in pancreatitis - the effects of tobacco on the pancreas [Internet]. [cited 2021 Feb 11]; Available from: https://virgo.org.ua/index. php/gastroenterologiya/10352-kurinnja-pri-pankreatiti-vplivtjutjunu- Ukrainian.

14. Leshchenko IV. [Structural and functional state of the pancreas under conditions of obesity [abstract].
Taras Shevchenko National University of Kyiv, Ministry of Education and Science of Ukraine, 2020. 21p. Ukrainian.

15. Grigorova NV, Khmelevska AP. [The state of pancreatic $\beta$-cells of adult and old mice after exposure to acute starvation and atropine]. Aktual pyt biol, ekol i khim. 2016;12(2) : 33-40. Ukrainian.

16. Yanko RV. [Morphological changes pancreas after of melatonin's effect in different seasons]. Fisiol zhurn. 2016;62(6): 88-94. Ukrainian.

17. Davydova NV. [Characteristics of influence produced by melatonin on some biochemical parameters of rat blood plasma at alloxan diabetes]. Aktual probl such med. 2016;16(4(1)): 242-4. Russian.

18. Zakharova IV. [The structure of the pancreas after exposure to gravitational overload theory]. Morfol. 2006;129(1): 60-5. Russian.

19. Slynko TN, Velikorodova MYa, Zarechnova NN. [Structured pancreas changes in deadaptation process to high altitude]. Vest Sib med. 2009;(1(2)): 69-72. Russian.

20. Barkhina TG, Donskoy MV, Savishchev AV. [Pancreas ultrastructure under conditions of changing gas environment]. Sat. scientific. proceedings of the All-Russian jubilee conference of pathologists dedicated to the 100th anniversary of prof. P.G. Podzolkova. Krasnoyarsk: 2008; 94-95. Russian.

21. Savishchev AV, Moldavskaya AA. Pancreatic morphogenesis at the stages of ontogenesis in experimental modeling under the influence of stress factors. [Морфporeнез поджелудочной железы на этапах онтогенеза при экспериментальном моделировании под воздействием стрессогенных фрактор] Moscow: Astrakhan; 2011. Russian.

22. Stepanyan YuS. [Morphofunctional equivalents of reaction pancreas on general overcooling]. Probl ekspert v med. 2008;(2): 22-4. Russian.

23. Doroshkevych SV, Pyvchenko PG, Doroshkevich EY. [Experience in cryomodelling pancreatic pathology]. Eksperim i klin gastroent. 2010;(8): 52-5. Russian.

24. Kurzanov AN, Zabolotskikh NV, Myasnikova VV, Shestopalov AV. [Pathophysiological aspects of experimental cryomodeling of pathological conditions of the pancreas]. Kuban nauchn med zhurn. 2016;6(116): 97-100. Russian.

25. SavishchevAV. [Electron-microscopic characteristics of the pancreas with a change in temperature]. Izvest vyssh ucheb zav. Povolzh reg. Med nauki. 2010;4(16): 11-7. Russian.

26. Kovchun VYU, Sikora VZ, Lindin MS, Sikora VV. [Histomorphometric assessment of changes in the parenchyma of the pancreas under the influence of hyperosmolar dehydration]. Bukovyn med visn. 2020;24(2): 52-6. Ukrainian.

27. Lazarenko LV, Kosareva PV, Samodelkin El, Khorinko VP. [Pathomorphological changes in rat pancreatic tissues caused by long administration of nimesulide]. Perm med zhurn. 2016;XXXIII(4): 78-81. Russian.

28. Viktorov OP. [Adverse reactions to medical drugs and the pancreas]. Zdorov Ukr. 2009; Thematic number: 5657. Ukrainian.

29. Ostapenko OV, Chaikovsky YuB. [Ultrastructural changes of rats pancreas acynocytes in the dynamics of congenital hypothyroidism development]. Biomed. 2014;(1): 38-44. Russian. 
30. Utekhin VJ. [Pancreatic epithelium under the hypothyroid condition]. Vest S of St. Petersburg University. 2015;(2): 89-111. Russian.

31. Abramovich AA, Styazhkina SN, Sharipova $\mathrm{AH}$. [Clinical case in surgical practice: acute idiopathic pancreatitis, complicated by multiple abscesses of the cerebral hemispheres]. Nauch zhurn dlya stud i prepod. 2021;(1): 125-30. Russian.

32. Ametov AS, Pugovkina YaV. [Glucose homeostasis and metabolic flexibility in healthy individuals]. Endokrinol: nov, mnen, obuch. 2020;9(4): 12-22. DOI: https://doi. org/10.33029/2304-9529-2020-9-4-12-22. Russian.

33. Ubaydullaeva VU, Fayazov AJ, Tulyaganov DB Vervekina TA, Kamilov UR. [Morphological changes of internal organs in electrical trauma in laboratory animal models]. Vest ekstren med. 2019;12(1): 54-61. Russian.

34. Zubritsky MG. [Morphological changes in the pancreas in acute herpetic meningoencephalitis]. Zhurn Grodno gos med univer. 2006;(1): 53-6. Russian.

35. Babinets LS, Scheigen OR. [Infectious factors in the formation of pathology of the pancreas. Medical newspaper "Health of Ukraine of the 21st century". [Internet]].2017 [cited 2021 Feb 11]; Jan 1 (398). Available from: http:// health-ua.com/article/25968-nfektcjn-chinniki-uformuvannpatolog-pdshlunkovo-zalozi. Ukrainian.

36. Babenko AYu, Laevskaya MYu. [Diabetes mellitus and COVID 19. How are they connected? Current strategy of fight]. Arterialnaya gipertenziya. 2020;26(3): 304-11. DOI:10.18705/1607-419X-2020-26-3-304-311. Russian.

37. Sabirova A. Mamytova A. Akramov I, Sabirov I. [New coronavirus infection (covid-19) and diabetes mellitus: a dentist's view]. The Scientific Heritage. 2021;(58):44-51. Russian.

38. Elbassuoni EA, Abdel Hafez SM. Impact of chronic exercise on counteracting chronic stress-induced functional and morphological pancreatic changes in male albino rats. Cell Stress Chaperones. 2019;24(3): 567-80. DOI: 10.1007/ s12192-019-00988.

39. Hew J, Parungao R, Shi $H$, Tsai K, Kim S, Ma D, Malcolm J, Li Zh,. Maitz P. Wang Y. Mouse models in burns research: Characterisation of the hypermetabolic response to burn injury. Burns. 2020;46(3): 663-74. DOI: https://doi. org/10.1016/j.burns.2019.09.014 